\title{
Economic Analysis of Troll Line Fisheries in Androth, Lakshadweep, India
}

\author{
A. Vinay ${ }^{1}$, V. Ramasubramanian ${ }^{2 *}$, P. Abdul Azeez ${ }^{3}$, \\ Rajan Kumar $^{3}$ and Dhandi Kranthi Kumar ${ }^{1}$ \\ ${ }^{1}$ Fisheries Economics, Extension and Statistics Division, ICAR-Central Institute of \\ Fisheries Education, PanchMarg, Off Yari Road, Versova, Andheri (W), \\ Mumbai - 400 061, Maharashtra, India \\ ${ }^{2}$ Division of Forecasting and Agricultural Systems Modelling, ICAR-Indian Agricultural \\ Statistics Research Institute (IASRI), PUSA, New Delhi, India \\ ${ }^{3}$ ICAR - Central Marine Fisheries Research Institute, Veraval Regional Centre, Gujarat, India \\ *Corresponding author
}

\section{A B S T R A C T}

Keywords

Lakshadweep,

Economic analysis,

B-C ratio, Troll line

and sharing systems.

Article Info

Accepted:

24 September 2017

Available Online:

10 November 2017
Troll line fisheries of Androth islands of Lakshadweep has basically two types of sharing systems showing different $\mathrm{BC}$ ratios - 1.55 was observed for $2 / 3$ sharing system against relatively lower value of 1.23 for $1 / 2$ sharing system. In troll line operation, the major fixed cost involved is interest on fixed capital accounting for $52.93 \%$ of total fixed cost. Fuel accounted for a massive $78.33 \%$ contribution to the variable cost. The operating cost ratio for $1 / 2$ and $2 / 3$ sharing systems were 0.75 and 0.59 respectively and the current estimate of labour productivity was estimated as Rs. 3088.09.

\section{Introduction}

The union territory of Lakshadweep is a chain of 36 islands covering an area of 32 sq. $\mathrm{km}$ out of which 11 are inhabited and 25 islands are uninhabited (Pillai et al., 2006). These being oceanic islands, the continental shelf area around them are limited to 4336 sq.km. However, the lagoons altogether have an area of 4200 sq.km offering immense biotic diversity. Also, the territorial waters of 400000 sq.km around the island offer extensive fisheries potential. Lakshadweep has a long history of being a traditionally maritime community of sailors, traders and fishers. The socio-economic mainstay of the local community is coconuts and maritime fish caught mostly through traditional fishing methods (Modayil, 2006). It is estimated that about $13 \%$ of the total population of Union territory of Lakshadweep are active, full-time fishermen and fisheries sector provide a livelihood to about $60 \%$ of the people of Lakshadweep. The fisheries of Lakshadweep can be broadly divided into Tuna Fishery, Non-Tuna Fishery (comprising of Sharks, Seer fishers, Rays, Perches, etc.) and Marine Ornamental Fishes. The fishing season of the 
Lakshadweep is from October to May. The major fishing activity revolves around the Pole and Line fishing of the Skipjack Tuna (Katsuwonus pelamis). It is estimated that the exploitable potential of Tuna from the Union territory of Lakshadweep waters is 150000 tonnes. The total fishable potential of nonTuna resources of Union territory of Lakshadweep waters is 100000 tonnes provided, there is a significant development in the introduction and use of non-traditional fishing techniques like Trolling, Long Lining, Perch Traps, etc., (Zacharia, 2007).

The main fishing method practiced in Lakshadweep islands is pole and line except Androthwhere troll line is the major fishing method (Pillai et al., 2006). Pole and line for tuna using live bait are the most important gear for tuna fishery with a contribution of $92.8 \%$ followed by troll line, drift gill net and handline, contributing $3.3 \%, 2.1 \%$ and $1.9 \%$ respectively. In Androth, troll line is the major fishing method (CMFRI, 2010-11). As per the basic statistics (UTL Basic Statistics, 2012) there are about 2017 fishing boats in Lakshadweep.

Androth is the only island in Lakshadweep group of islands without any lagoon formation (Varghese, 1987).It is situated 293 $\mathrm{km}$ from Kochi. Its location corresponds to the latitude $10^{\circ} 49^{\prime} \mathrm{N}$ and longitude $73^{\circ} 40^{\prime} \mathrm{E}$. The land area is 4.9 sq. $\mathrm{Km}$, biggest of all islands. Androth has a population of 11191 (UTL Basic Statistics, 2012). Fishing is carried out almost throughout the year. The major method of fishing is trolling which is in contrast to the other islands where pole and line dominates. This could be attributed to the fact that success of pole and line fishing depends on availability, catching and presentation of baits inhabiting in lagoon which is absent in the case of Androth (Varghese, 1987; James et al., 1987).
The estimated potential of tuna and non-tuna resources of the island is1.5 and 1.0 lakh tonnes respectively (Zacharia, 2007) which in turn decides the socio-economic fate of the local inhabitants. A dedicated analysis of economic performance of fishing activity in each island is pre-requisite to plan any developmental strategy. As in Androth island, troll line is the major act of fishing, current study is dedicated towards highlighting the modes of fishery operation, cost and revenue involved in fishery activity along with assessment of economic performance of the sector and revenue sharing pattern among stakeholders.

\section{Materials and Methods}

\section{Troll line fishing method in Androth, Lakshadweep}

There are basically three locally modified versions of troll lines which are in operation along Androth island, Lakshadweep. The most common one is with two extended bamboo poles (2-3metre) required for the operation of the troll lines. Normally 9 nylon monofilament troll lines (No. 70-80) are being operated with four lines operated from outrigger bamboo poles and have single hook (No. 6 to 8). Remaining five lines are attached to the fishing platform (frame) at the aft side of the vessel. The length of the troll line are not uniform, the outermost and innermost are of 50-55metre length (No. 80-120) with the chain of hooks (No. 6-8) and remaining one are of 15-30 metre length with single hook (No. 6-8). The longer lines are provided with fish belly pieces as bait whereas smaller lines and lines attached to bamboo poles are with artificial bait. The chain of hook contains 815 hooks spaced at 1.5 to 2 metres. The secondary line (No. 70-110) joining hooks to main line are of 1.5 to 2 metre length. When large fishes are expected in catch, the inner line is provided with secondary steel wire (1 
metre) having single hook (No. 1). The hook size is changed with the expected size of the catch. During the month of June and July, No. 6 sized hooks are used and in rest of the months, No. 8 sized hooks are used. The other two types of versions do not have the outrigger bamboo poles. One of the version is similar to the above explained one with the exception that it does not have bamboo poles. The third method which is normally practised when the target fish abundance is less has 2 to 3 main line attached to fishing platform at the aft side of the platform. Each main line has 8 to 15 secondary line at an interval of 1.5 to 2 metres.

The islands of Lakshadweep are famous for pole and line tuna fishery. The Androth island is different as it does not have a dominant pole and line fishery which point to the fact that it does not have a lagoon limiting the amount of bait fishery which is the prime prerequisite for established pole and line fishery. This has led to the emergence of other method of fisheries like trolling and gill netting.

Trolling is a single day operation spanning over 6 to 7 hours with fishers going early in the morning and returning in the afternoon. Sometimes fishers undertake two trips in a day. Trolling operations are carried out at the speed of 6 to 7 nautical miles per hour. Troll lines require frequent replacement due to wear and tear but complete one time replacement is not there. Trolling operations are carried out year round but the catches are less during monsoon season.

\section{Fish marketing in Androth}

The troll line catches is dominated by yellow fin tuna, little tuna, frigate tuna and other species caught are skip jack tuna, marlins, shark, seer fish and sword fish etc. Most of the catches are sold in fresh condition. It is in contrast to other islands for the handsome chunk of catches goes for masmin production that to glut season. The fishes are seldom sold as whole fish rather they are sold in pieces. The normal thickness of pieces is three fingered size during good catches and thumb size during lean season. In cases where fishes are of very large size (example: marlin) the pieces are further divided horizontally. The price range of different fishes in Androth is given in the Table 1.

\section{Sampling setup for data collection}

Of all the group of Lakshadweep islands (Fig. 1), as three islands viz., Minicoy, Androth, Agatti have been reported to have most of the fish catch (CMFRI annual report 2012-2013). Androth (Fig. 2) has been selected for present study owing to the fact that, it is the only island there is no lagoon formation it results in absence of live bait intern results in absence of pole and line fishery so it gives a way to existence of troll line.

The period of primary data collection was during October-November 2014. In all, 28 number of fishers who were predominantly boat owners were contacted for economic analysis.

It is mentioned here that the total number of mechanized boats in Androth is around 60 of which majority employ troll line fishing. Hence it can be stated that around $50 \%$ of the boat owners from the selected island have been covered, thus the sampling fraction is around 0.5 , as a conservative estimate. On each day of data collection, the landing hours are usually between 4 to $8 \mathrm{PM}$ in the evening. On any given day, around 15 to 20 boats land at the landing place. From this, around 2 to 3 boat owners/ fishers were covered at the landing/ marketing place. In this way, random selection of boat owners/ fishers has been fairly ensured. 


\section{Initial investment}

It comprises of cost of hull, engine and others (GPS, compass).

\section{Fixed cost}

A cost that does not change with an increase or decrease in the level of production is called fixed cost. Fixed cost is the expenses that have to be paid by a farm, independent of any business activity.

It is one of the two components of the total cost, along with variable cost. Fixed cost includes following aspects:

Depreciation on fixed assets: calculated using straight line method

Interest on fixed capital: calculated @ 12\% per annum on fixed capital.

Expenses on repair and maintenance of fixed assets: estimated based on the information collected from sampled boat owners and fishers.

\section{Variable cost}

Variable cost is that part of the total cost which changes with change in output level.

The daily expenses incurred are termed as operating cost or variable cost. It includes the following aspects:

\section{Variable cost for tuna fishing}

Fuel

Lubricant

Food

Carpenter cost

Gear maintenance cost

Interest on working capital (calculated at 8.5 $\%$ interest rate)

\section{Gross income}

It was worked out by multiplying the quantity of fish with their respective prices.

Gross income $=Q P$

Where,

$\mathrm{Q}=$ quantity of produce $(\mathrm{kg})$

$\mathrm{P}=$ Selling price $(\square / \mathrm{kg})$

\section{Net income}

It is the return left after deducting all the expenditure such as fixed cost and variable cost from gross income.

Net income $=G I-T C$

Where,

$\mathrm{GI}=$ Gross income

$\mathrm{TC}=$ Total cost

$T C=T F C+T V C$

Where,

$\mathrm{TFC}=$ Total fixed cost

$\mathrm{TVC}=$ Total variable cost

Benefit Cost Ratio (B: C Ratio) or return over investment ratio

$\mathrm{B}$ : $\mathrm{C}$ ratio was used to ascertain the viability of the business. It estimates the ratio of benefit and cost incurred in the business. Mathematically, it can be expressed as

B: $C$ Ratio $=\frac{\text { Gross income }}{T_{n \rightarrow m} \sim n o t r}$

\section{Number of fishing days}

The number of days calculated for troll line fishery was 260 days owing to the fact that 
troll lines are operated during monsoon season also. Total number of fishing days was arrived at by subtracting number of holidays like Fridays, the month of Ramzan and other regional holidays based on consultation with fishers and officials from fisheries department. In addition to that, 20 days have been deducted from the remaining days for repair and other works. The days have been worked out based on an inquiry from fishers. The distribution of these days along the different fishing months is uniform assuming the random nature of maintenance and repair requirements.

\section{Price of fresh fish and fish landing}

The selling price of fresh fish for a month has been estimated based on interview with fishers, data enumerators of fisheries department and self-observation during the months of September, October and November 2014. For the rest of the months, the figures are solely based on interviews. For both price and landings, their averages for the month were used for analysis. In cases where data in individual interview seem to be either very low or high than the majority of values, they were omitted from the calculation of average values.

The operating ratio or capital productivity ratio and labour productivity were considered as the indicators of economic efficiency of the unit (Geetha et al., 2014)

Operating ratio or Capital productivity = Operating costs/ Gross revenue

Labour productivity $=$ Gross revenue $/$ Man days

\section{Sharing system}

Revenue sharing in troll line fisheries of Androth has two types of sharing systems, one with 50\% share going to boat owners and remaining to fishers, which is most prevalent. The other sharing system is highly in favor of boat owners with $2 / 3^{\text {rd }}$ of share.

\section{Results and Discussion}

\section{Initial investment in Troll line fishing fishing units}

The components of troll line fishing unit like hull and engines are capital intensive which makes troll line fishing, a high initial investment proposition. The initial investment across the Androth island is around Rs. 5.40 lakhs per vessel (Table 2).

\section{Economic evaluation of troll line fisheries in Androth, Lakshadweep (Table 2)}

Androth is the second most populous island with less number of fishing vessels and higher number of fish consumers making the price of the fish relatively higher than the other islands.

In addition to that, entire catch is sold as fresh which is quite different from other islands where major share goes for masmin production. In rare cases, when the catch of tuna is high, they prepare masmin in this island. Economic evaluation of troll line fishery of Androth reveals that interest on fixed capital $(52.93 \%)$ is the major fixed cost whereas fuel $(78.33 \%)$ dominates among the variable costs.

In Androth island, there exists two systems of revenue sharing. In one of the systems, half of the generated revenue goes as fishers share and remaining 50\% share for boat owners who are responsible for the maintenance and operation of the boat. The higher net profit in $2 / 3$ system was obvious owing to the fact that a massive $2 / 3^{\text {rd }}$ of total generated revenue was claimed by boat owner. 
Table.1 Price range of different fishes in Androth

\begin{tabular}{|l|l|r|}
\hline Sl.no & Fish species & Rupees per kg \\
\hline 1 & Yellow fin tuna & $150-350$ \\
\hline 2 & Skip jack tuna & $100-200$ \\
\hline 3 & Little tuna and Frigate tuna & $50-150$ \\
\hline 4 & Shark & $100-250$ \\
\hline 5 & Seer fish & $100-200$ \\
\hline 6 & Marlins and Sail fish & $200-350$ \\
\hline 7 & Gar fish & 100 \\
\hline
\end{tabular}

Table.2 Economic analysis of troll line fisheries in Androth, Lakshadweep

\begin{tabular}{|l|r|r|r|r|}
\hline & $\mathbf{1 / 2}$ share (Rs.) & \multicolumn{1}{|c|}{$\%$} & $\mathbf{2 / 3}$ share (Rs.) & \multicolumn{1}{c|}{$\%$} \\
\hline Initial Investment Rs. (x 1000) & & & & \\
\hline Hull & 370.00 & 68.42 & 370.00 & 68.42 \\
\hline Engine & 158.93 & 29.39 & 158.93 & 29.39 \\
\hline Others & 11.89 & 2.20 & 11.89 & 2.20 \\
\hline Total & 540.81 & $\mathbf{1 0 0 . 0 0}$ & 540.81 & $\mathbf{1 0 0 . 0 0}$ \\
\hline Fixed cost Rs. (x 1000)/Annum & & & & \\
\hline Interest on fixed capital & 64.90 & 52.93 & 64.90 & 52.93 \\
\hline Depreciation & 35.83 & 29.22 & 35.83 & 29.22 \\
\hline Maintenance & 21.88 & 17.84 & 21.88 & 17.84 \\
\hline Total fixed cost (A) & 122.61 & $\mathbf{1 0 0 . 0 0}$ & 122.61 & $\mathbf{1 0 0 . 0 0}$ \\
\hline Variable Cost Rs. (x 1000)/Annum & & & & \\
\hline Carpenter & 5.72 & 1.00 & 5.72 & 1.00 \\
\hline Fuel & 447.78 & 78.33 & 447.78 & 78.33 \\
\hline Lubricant & 19.64 & 3.43 & 19.64 & 3.43 \\
\hline Food & 83.11 & 14.53 & 83.11 & 14.53 \\
\hline Working capital & 571.64 & $\mathbf{1 0 0 . 0 0}$ & 571.64 & $\mathbf{1 0 0 . 0 0}$ \\
\hline Interest on working capital & 48.59 & & 48.59 & \\
\hline Total variable cost (B) & 620.23 & & 620.23 & \\
\hline Total revenue & 2408.71 & & 2408.71 & \\
\hline Fishers share (C) & 1204.36 & & 802.90 & \\
\hline Boat owner share & 1204.36 & & 1605.81 & \\
\hline Total Cost [D=(A+B+C)] & 1947.20 & & 1545.74 & \\
\hline B-C ratio & $\mathbf{1 . 2 3}$ & & $\mathbf{1 . 5 5}$ & \\
\hline Operating Ratio & $\mathbf{0 . 7 5}$ & & $\mathbf{0 . 5 9}$ & \\
\hline Labour Productivity & $\mathbf{3 0 8 8 . 0 9}$ & & $\mathbf{3 0 8 8 . 0 9}$ & \\
\hline
\end{tabular}


Fig.1 Map of Lakshadweep

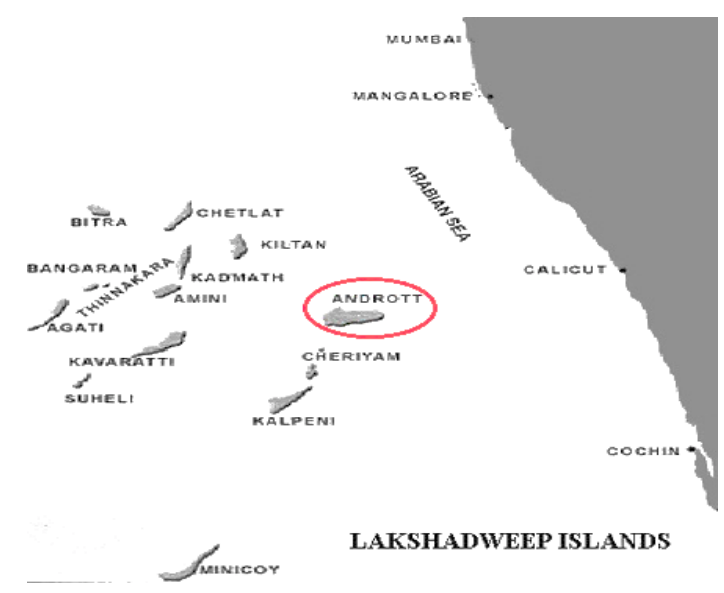

Fig.2 Androth island of Lakshadweep considered in the present study

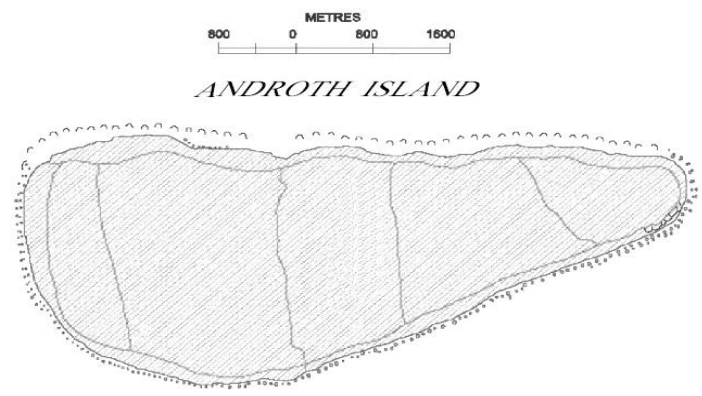

The gross profit for troll line fishing was estimated as Rs. 24.08 lakhs / annum. The net profit for $1 / 2$ and $2 / 3$ sharing system were Rs. 4.62 lakhs and 8.63 lakhs respectively. The operating cost ratio explains the percentage of gross income spent toward operating expenses. The operating cost ratio for $1 / 2$ and $2 / 3$ sharing system were 0.75 and 0.59 respectively highlighting higher operating expenditure in $1 / 2$ sharing system which could be attributed to the larger fisher share in this sharing system. The comparative analysis of $1 / 2$ and $2 / 3$ sharing system of troll line fishing units in Androth showed that $2 / 3$ sharing system showing the highest capital productivity with lowest operating ratio of 0.59 whereas 0.75 for $1 / 2$ sharing system. The highest earning of $2 / 3$ sharing system is owing to the fact that $2 / 3$ of the catch is hold by boat owner itself.
The operating cost ratio of $1 / 2$ sharing system was comparable to that of single day gill netters and single day trawler (0.69-0.70) and was higher than single day purse seiner (0.60) (Aswathy et al., 2011) operating along Kerala coast. The ratio for $2 / 3$ sharing system (0.59) was drastically lower than other fishing system barring the single day purse seiner whose values were was quite similar to the present estimates. The higher value of 0.75 in $1 / 2$ sharing system seems to be less profitable to the boat owner but definitely more socially justifiable for the fishers onboard.

The labour productivity (LP) indicates the total output in terms of revenue per labourman days. The current estimates of LP was Rs. 3088.09 which are similar to the multi-day gillnetters (Rs.3131.00), marginally higher than multiday trawlers (Rs. 2739.00) 
operated along Chennai coast (Geetha et al., 2014) and significantly higher than purseseiners (Rs. 1354.00) and single day gillnetters (Rs. 842.00) operated along Kerala coast (Aswathy et al., 2011).

The analysis of $\mathrm{B}-\mathrm{C}$ ratio gives a figure of 1.23 (1/2 sharing system) which is drastically lower than the $\mathrm{B}-\mathrm{C}$ ratio of 1.55 for $2 / 3$ sharing system. In the second type of sharing system $2 / 3^{\text {rd }}$ of the revenue goes to the boat owners and rest to the fishers. The first sharing system is more widely practiced than the second one. It was also observed that the second system is gradually being replaced by first one.

\section{Acknowledgements}

The authors are grateful to Head, Fisheries Economics, Extension and Statistics Division and also to Director and Vice-Chancellor, ICAR-CIFE, Mumbai for providing funds and facilities for conducting this study. The support extended by Department of Fisheries, Lakshadweep is also duly acknowledged.

\section{References}

Anon. (2010-11) - Annual report. 23-24p, Central Marine Fisheries Research Institute, Cochin, India.

Anon. (2012-13) - Annual report. 1656p,Central Marine Fisheries Research Institute, Cochin, India.

Anon. (2012-13) - Basic Statistics,19-20p, Directorate of Planning and Statistics, Secretariat, Lakshadweep, Kavaratti, India.
Aswathy, N. A., Shanmugam, T. R., and Sathiadhas, R. 2011. Economic viability of mechanized fishing units and socioeconomics of fishing ban in Kerala. Indian J. Fish. 58(2): 115-120.

Geetha, R., Narayanakumar, R., Salim, S. S., Aswathy, N., Chandrasekar, S., Raghavan, V. S., and Divipala, I. (2014) Economic efficiency of mechanised fishing in Tamil Nadu - a case study in Chennai. Indian J. Fish., 61(4) 31-35.

James, P. S. B. R., Gopakumar, G., and Pillai, P. P. 1987. Small-scale pole and line tuna fishery in Lakshadweep-present trend, constraints and strategies for future developments. Marine Fisheries Information Service, Technical and Extension Series, 77: 1-10.

Modayil, M.J. 1991. Island fisheries of India. In: Handbook of Fisheries and Aquaculture, edited by S. Ayyappan, 135-142p,ICAR., New Delhi, India.

Pillai, N.G.K, Vivekanandan, E and Said Koya, K.P. 2006. Marine fisheries information service, ISSN 0254-380X,. pp. no.187.

Varghese., G. 1987. Status and programmes of marine fisheries development and managaement in Lakshadweep. National symposium on research and development in marine fisheries CMFRI Bulletin, Mandapam camp.561-576p, Central Marine Fisheries Research Institute, India.

Zacharia, S. 2007. Fisheries of Lakshadweep with special reference to livelihood issues, At: https://www.nabard.org/ pdf/Fisheries.pdf, (Accessed on 21April-2014).

\section{How to cite this article:}

Vinay, A., V. Ramasubramanian, P. Abdul Azeez, Rajan Kumar and Dhandi Kranthi Kumar. 2017. Economic Analysis of Troll Line Fisheries in Androth, Lakshadweep, India. Int.J.Curr.Microbiol.App.Sci. 6(11): 3172-3179. doi: https://doi.org/10.20546/ijcmas.2017.611.372 